\title{
SEC23B wt Allele
}

National Cancer Institute

\section{Source}

National Cancer Institute. SEC23B wt Allele. NCI Thesaurus. Code C97934.

Human SEC23B wild-type allele is located in the vicinity of 20p11.23 and is approximately $54 \mathrm{~kb}$ in length. This allele, which encodes protein transport protein Sec23B, is involved in the transport of vesicles from the endoplasmic reticulum to the Golgi. Mutation of the gene is associated with congenital dyserythropoietic anemia type II. 